Отримано: 29 серпня 2018 р.

Прорецензовано: 04 вересня 2018 р.

Прийнято до друку: 12 вересня 2018 р.

e-mail: sych.dima@gmail.com

DOI: $10.25264 / 2311-5149-2018-10(38)-30-36$
Сич Д. М. Інструментарій управлінського аналізу фінансових результатів. Наукові записки Начіонального університету "Острозька академія». Серія “Економіка» : науковий журнал. Острог : Вид-во НаУОА, вересень 2018. № 10(38). С. 30-36.

Сич Дмитро Миколайович,

аспірант Національного університету водного господарства та природокористування, м. Рівне

\title{
ІНСТРУМЕНТАРІЙ УПРАВЛІНСЬКОГО АНАЛІЗУ ФІНАНСОВИХ РЕЗУЛЬТАТІВ
}

Стаття присвячена організачї управлінського аналізу фінансових результатів на прикладі виробничих підприємств України. Узагальнено функиії управлінського аналізу як інформаційної основисистеми менеджменту на засадах збалансованості підприємницької діяльності. Розкрито методичні підходи до управлінського аналізу, альтернативні иляхи формування необхідного рівня деталізації управлінської інформації, їі відповідності цільовим запитам менеджменту. Розглянуто сучасні інформаційні технології аналітичних досліджень облікових даних у розрізі показників результативності (затрат, продукту, прибутковості й оцінки якості) з використанням інструментарію управлінського аналізу.

Ключові слова: виробниче підприємство, управлінський аналіз, методичний інструментарій, збалансованість підприємницької діяльності, показники результативності.

\section{Сыч Дмитрий Николаевич,}

аспирант Национального университета водного хозяйства и природопользования, г. Ровно

\section{ИНСТРУМЕНТАРИЙ УПРАВЛЕНЧЕСКОГО АНАЛИЗА ФИНАНСОВЫХ РЕЗУЛЬТАТОВ}

Статья посвячена организации управленческого анализа финансовых результатов на примере производственных предприятий Украины. Обобщены функиии управленческого анализа как информационной основы системы менеджмента на основе сбалансированности предпринимательской деятельности. Раскрыты методические подходы к управленческому анализу, альтернативне пути формирования необходимого уровня детализации управленческой информации, ее соответствия иелевым запросам менеджмента. Рассмотрены современные информационные технологи аналитических исследований учетных данных в разрезе показателей результативности (затрат, продукта, прибыльности и оценкикачества) с использованием инструментария управленческого анализа.

Ключевые слова: производственное предприятие, управленческий анализ, методический инструментарий, сбалансированность предпринимательской деятельности, показатели результативности.

\author{
Dmytro Sytch, \\ a graduate student in National University of Water and Environmental Engineering, Rivne
}

\section{INSTRUMENTARY FOR THE MANAGERIAL ANALYSIS OF FINANCIAL RESULTS}

The article is devoted to the organization of managerial analysis of financial results on the example of Ukrainian manufacturing enterprises. The functions of managerial analysis as the information source for the management system based on balanced entrepreneurial activity are generalized. The methodical approaches to managerial analysis, alternative ways of forming the necessary level of the management information detail, its conformity to the target management requests were revealed. It was established that the integration of production enterprises into international markets necessitates the development of methodological and organizational tools for economic analysis of the economic activity. Production resources, capital (own, attracted), financial results are defined as the objects of managerial analysis. In turn efficiency resources, effectiveness of production business processes, financial results optimization in the market conditions are seen as the subject of managerial analysis. The modern information technologies of accounting data analysis in terms of performance indicators (costs, product, profitability and quality assessment) with the use of the tools of managerial analysis are considered.

Key words: production enterprise, managerial analysis, methodical tools, business activity balance, performance indicators.

Постановка проблеми. Від об’єктивної і повної оцінки даних економічного аналізу фінансових результатів залежить дієвість та ефективність господарювання виробничого підприємства. Науковці-аналітики до організації аналізу фінансових результатів висувають низку вимог: аналіз базується на сучасних досягненнях науки та практичного досвіду, враховує дію економічних законів на певному підприємстві, використовує науково обгрунтовані методики, враховує особливості ринкових умов і галузеву специфіку. Сучасні технології оперативного та перспективного управління потребують деталізованих аналітичних даних щодо факторів впливу на формування доходів і витрат, що не завжди можливо з використанням методів економічного аналізу. 
Аналіз останніх досліджень і публікацій. Значний вклад у дослідження проблем теорії та методології формування обліково-аналітичної системи внесли такі науковці: Ф. Ф. Бутинець [1], М. А. Вахрушина [2], І. В. Замула [3], С. 3. Мошинський [3], О. В. Олійник [3], В. С. Рудницький [4], М. С. Пушкар [5], В. В. Сопко [6], Дж. Фостер, Ч. Т. Хорнгрен [7] та ін.

Проблема вибору ефективного інструментарію управлінського аналізу фінансових результатів господарської діяльності, який враховував би специфіку виробничих підприємств, їх галузеві організаційноекономічні особливості, залишається не вирішеною. Це свідчить про актуальність питання, що зумовлює напрям дослідження в науковому і практичному аспектах.

Метою і завданням дослідження є: оцінка наявного та дослідження нового, альтернативного інструментарію управлінського аналізу фінансових результатів на прикладі вітчизняних виробничих підприємств; обгрунтування ефективної організації аналітичних процедур із використанням даних бухгалтерського обліку, а також на основі дослідження результативності управління господарськими операціями, що впливають на формування зазначених показників.

Виклад основного матеріалу. Підтримуючи позицію І. В. Замули, С. З. Мошенського, О. В. Олійник, організацію економічного аналізу фінансових результатів на підприємстві доцільно здійснювати в такій послідовності:

- визначення завдань, вибір об’єктів і організаційних форм аналітичного дослідження;

- формування плану економічного аналізу фінансових результатів і ресурсного забезпечення його виконання;

- визначення об'єктивного, максимально повного інформаційного і методичного забезпечення аналітичних процедур у розрізі доходів, витрат, прибутку/збитку й операцій, що їх формують;

- систематизації результатів аналітичної обробки показників;

- узагальнення результатів аналізу фінансових результатів відповідно до поставлених завдань за цільовими потребами менеджерів;

- дослідження результатів попереднього внутрішнього контролю щодо реалізації пропозицій, зроблених за результатами аналізу.

Предметом аналізу є аналітичне дослідження: господарських операцій формування показників фінансового результату діяльності підприємства; раціонального використання прибутку/погашення збитків із урахуванням економічного потенціалу підприємства [3].

Сучасні методики економічного аналізу господарської діяльності практично «обходять» застосування аналітичних процедур до прийняття та виконання заходів адміністрування операцій. Водночас ринкові відносини та їх регулювання на державному, суспільному та наукових рівнях обумовлюють потребу системного моніторингу в питаннях компетентності та результативності управління процесами використання, збереження та відновлення виробничих ресурсів.

Однак питання моніторингу управління виробничими ресурсами підприємства економічний аналіз не передбачає. Це ускладнює формулювання виваженого причинно-наслідкового характеру виявлених аналізом відхилень із питань ефективності, раціональності, технологічної можливості та доцільності використання виробничих ресурсів.

Завдяки залученню до аналізу працівників із різними знаннями, компетенцією з питань, які досліджують (зокрема, спеціалістів управлінського складу), можна досконало ідентифікувати проблеми, знайти оптимальні підходи щодо їх вирішення та/або попередження.

Виробничо-господарська діяльність $є$ накладенням бізнес-процесів на ресурси. Менеджмент підприємства базується не тільки на інформації щодо динаміки руху виробничих ресурсів, оскільки на етапах формування збалансованої соціально-економічної й екологічної складових сучасного підприємництва важливою є комплексна управлінсько-економічна аналітична база, яку в нашій роботі розглянуто в межах управлінського аналізу.

Об 'єкти управлінського аналізу - виробничі ресурси, капітал (власний, залучений), фінансові результати.

Предметом управлінського аналізу є: ефективність використання виробничих ресурсів, результативність виробничих бізнес-процесів, оптимізація фінансових результатів у сучасних ринкових умовах.

За теорією менеджменту в системі управління виділяють керуючу і керовану системи як взаємопов'язані елементи:

- керуюча система - сукупність органів, засобів, інструментів і методів управління;

- керована система - виробничо-комерційний процес.

У роботі аналітичні процедури управлінського аналізу розглянуто за двома напрямами аналізу результативності:

I - фінансово-господарської діяльності на основі базових індикаторів;

II - адміністрування ретроспективної, оперативної та перспективної діяльності.

За другим напрямом визначають оцінку методів, яку застосовують під час розробки управлінських рішень, що можна узагальнити за кількома групами: 
1. Методи, які спираються на особистий досвід, набуті компетенції менеджерів, їх уміння комунікувати зі спеціалістами більш вузького профілю підготовки в конкретній галузі діяльності.

2. Методи, засновані на так званій «розумній логіці», інтуїції, довірі до думок керівників із відповідним фаховим рівнем управління.

3. Методи, засновані на науково-практичному підході: передбачають вибір оптимальних рішень із певного числа варіантів, розрахованих шляхом використання значного обсягу інформації.

4. Застосування комбінацій вищеперерахованих управлінських «логістичних кроків».

До методів 3-ої групи в міжнародній аналітичній практиці застосовують специфічні аналітичні процедури як інструмент операційного внутрішнього аудиту:

1. Процесний аналіз управління - аналіз ефективності й результативності системи менеджменту (процесів планування, організації, координації та контролю).

2. Функціональний аналіз управління: аналітичне дослідження результативності управління як компресу показників за окремими функціями (функція маркетингу, виробнича функція, функція постачання, функція управління фінансами, функція загального управління, функція управління персоналом).

3. Ситуаційний аналіз на предмет дослідження факторів впливу виробничо-комунікаційних взаємозв'язків у межах наявної системи управління : SWOT-аналіз, аналіз стратегічної позиції, займаної підприємством, аналіз сегментів ринку, аналіз конкуренції, позиційний аналіз тощо.

4. Внутрішній аналіз відповідності й взаємозв'язків у межах комплексної системи управління підприємством: комплексний аналіз ступеня інтеграції, автоматизації функціональних підсистем, аналіз інформаційних систем підтримки прийняття управлінських рішень [8].

Розвиток інформаційних технологій дозволяє використовувати для управлінського аналізу імітаційне моделювання з метою вирішення слабо структурованих завдань. За економіко-кібернетичним змістом імітаційне моделюва́ння розглядають як метод дослідження, заснований на тому, що систему, яку вивчають, замінюють імітатором (аналогом) із яким проводять експерименти з метою отримання інформації про цю систему [9].

Досить активно використовують підприємства великого бізнесу (як зарубіжні, так і вітчизняні) принципи оптимізації бізнес-процесів на основі аналізу результатів FCA-моделювання в системі Business Studio. Одним із ключових ефектів застосування процесного підходу до управління $\epsilon$ можливість точного визначення критичних для бізнес-систем ресурсів і операцій (наприклад, на етапах реалізації інноваційних проектів, структуризації виробництва тощо).

Системний аналіз бізнес-процесів містить такі етапи: опис (ідентификацію) елементарних операцій функціональних бізнес-процесів; визначення ланцюжкових зв'язків на основі множин елементарних операцій і синтезу наскрізних бізнес-процесів.

Основними показниками якості, які аналізують у межах бізнес-процесів, $є$ : ефективність (результативність / ресурсоємкість); оперативність; задоволення потреб споживача [10].

Імітаційне моделювання надає можливість експериментувати з виробничо-фінансовими процесами, які відбулись, припускаються (заплановані), ймовірно можуть бути за умови комбінації інших макро- та мезо-факторів суспільно-економічного розвитку. До таких процесів можна віднести: загальні парадигми розвитку фінансово-господарської системи підприємства; проекцію або теоретичну основу / гіпотезу, що уможливить розкриття напрямів соціально-економічної й екологічної складових господарювання (їх пріоритетне ресурсне забезпечення) як об'єкта аналізу, який вивчають; моделювання таких теорій для діагностики питань управління основними техніко-економічними показниками на найближчу перспективу.

Імітаційне моделювання значною мірою спирається на теорію інформаційних систем, математику, теорію ймовірності, статистику. В процесі побудови імітаційної моделі можуть використовувати регресійний і кореляційний види аналізу.

Управлінський аналіз інтегрує з видами економічного аналізу, залежно від вибору періоду дослідження, джерел формування інформаційної бази.

За першим напрямом застосування процедур управлінського аналізу досліджують результати фінансово-господарської діяльності виробничого підприємства.

Залежно від періоду аналітичного дослідження показників фінансово-господарської діяльності управлінський аналіз класифікують на:

- ретроспективний: визначення ефективності виробничо-господарської діяльності зіставленням витрат і результатів за різними об'єктами обліку і в різних тимчасових інтервалах;

- оперативний: оперативна оцінка короткострокових змін у стані об'єкта і виявлення можливостей доведення фактичного стану об'єкта до бажаного;

- перспективний: перспективного аналізу (короткострокового або стратегічного) належить підготовка інформації, корисної для ухвалення рішень, направлених у майбутнє $[1 ; 3]$.

Безпосередньо процес адміністрування операцій формування доходів/витрат визначає специфіку аналітичних процедур, рівень аналітичних субрахунків до рахунків бухгалтерського обліку, що загалом 
розкривається в розрізі основних і забезпечувальних функцій управління. Основні функції управління:

- планування: довгострокове, поточне й оперативне планування на основі виконання всіх видів робіт взаємопов'язаними етапами проводять: за комплексною оцінкою зовнішньої ситуації, визначення попиту на продукцію; створенням системи зв'язків і формування потоків інформації для планування; шляхом визначення головних цілей і завдань; відповідно до розробки спільних планів на тривалий період, поточних планів;

- внутрішній контроль/внутрішні аудит: слідує за інтегрованою системою бухгалтерського обліку. Містить системний внутрішній контроль із питань виконання планових завдань, нормативів і відхилень від них, а також за окремими питаннями оцінки фінансових результатів - внутрішній операційний аудит;

- організація виконання рішень: забезпечує формування просторово-часових відхилень, технологічно необхідних пропорцій у використанні бізнес-процесів, реалізацію заходів соціального захисту працівників та екологічної безпеки виробничої діяльності;

- коригування рішень на етапах їх виконання: забезпечує моніторинг дотримання запланованого напряму діяльності об'єкта управління, завдяки якому усувають випадкові відхилення системи.

Забезпечувальні функції в частині:

- управлінського обліку: функція, покликана відображати аналітичні результати виробничогосподарської діяльності підприємства, які в системі менеджменту є ключовими факторами досягнення збалансованості підприємницької діяльності. Забезпечує одержання даних про стан об'єкта управління за певний період, спирається на показники бухгалтерського обліку, а також містить облік прийняття та виконання адміністративних рішень;

- економічного аналізу: спираючись на дані бухгалтерського обліку та фінансової звітності, аналітична оцінка є основою для обгрунтованого планування, оперативного виконання планів та аналітичного дослідження результатів виконання плану.

Дві взаємопов'язані функції підготовки управлінських рішень визначають інструментарій управлінського аналізу, основними завданнями якого є обгрунтування оцінки ефективності кожного з напрямів аналітичних досліджень.

Управлінський аналіз розглядають у системі з обліком і контролем, однак він має суттєві відмінності:

- облік несе інформацію про стан об'єкта управління - управлінський аналіз розкриває причинно-наслідковий зв'язок динаміки стану;

- контроль встановлює лише факт самого відхилення - завданням управлінського аналізу є встановлення кореляції відхилень від нормативного/бажаного показника й альтернатив коригування на основі використання даних, накопичених обліком і контролем.

Враховуючи практичну спрямованість управлінського аналізу, серед завдань його інструментарію $\epsilon$ пріоритетними: встановлення закономірностей відхилень, їх системність; виявлення й обгрунтування факторів, що викликали конкретні причини виявленої динаміки; пошук резервів у разі усунення факторів негативного впливу; обгрунтування шляхів реалізації виробничого потенціалу, оцінка їх ефективності; оцінка альтернативних напрямів розвитку на перспективу.

Управлінський аналіз слугує інструментом підготовки управлінських рішень, оптимальність яких залежить від об'єктивності та достовірності дослідження внутрішньовиробничого та регуляторно-технологічного середовища виробничого підприємства, а саме:

- розробки облікової, податкової, амортизаційної, кредитної, маркетингової політики тощо;

- якості системи управління ресурсами, зобов'язаннями, капіталом виробничого підприємства;

- дієвості контрольних та аналітичних процедур загалом;

- ефективності правової та господарської вертикалі управління підприємством (власників, засновників, дирекції, складу правління тощо);

- іміджу підприємства на ринку, в регіоні тощо.

3 урахуванням комплексного характеру управлінського аналізу серед основних джерел інформації для проведення аналітичних процедур є:

- установчі документи підприємства (засновницький договір, статут), довідка про включення до ЄДРПОУ, свідоцтво про державну реєстрацію, реєстр власників акцій (за наявності), внутрішні Положення (про організацію розрахунків з оплати праці, про відрядження, про дотримання внутрішнього розпорядку тощо), Колективний договір підприємства;

- документи фінансової звітності, а саме: Баланс підприємства (форма N 1); Звіт про фінансові результати (форма N 2); Звіт про рух грошових коштів (форма N 3); Звіт про власний капітал (форма N 4); Примітки до річної фінансової звітності (форма N 5).

- форми статистичної звітності: Звіт про наявність і рух основних фондів, амортизацію (знос) (форма N 11-О3); обстеження технологічних інновацій промислового підприємства (форма N 1-інновація); Звіт про фінансові результати і дебіторську та кредиторську заборгованість (форма N 1-Б); Звіт із праці (форма N 1-ПВ); Звіт про стан умов праці, пільги та компенсації за роботу зі шкідливими умовами праці 
(форма N 1-ПВ (умови праці)); Звіт про використання робочого часу (форма N 3-ПВ); Звіт про виробництво промислової продукції (форма N 1П-НПП); інша інформація, необхідна для проведення аналізу та виявлення резервів виробництва [11].

Перелік базових показників, які використовують під час проведення аналізу фінансово-господарського стану підприємств, у роботі запропоновано узагальнити як систему результативних показників у складі:

- показників затрат: суми витрачених виробничих ресурсів (матеріальних, грошових) на ведення операційної діяльність (Форма № 1 «Баланс», Форма № 2 «Звіт про фінансові результати»; Форма № 3 «Звіт про рух грошових коштів»);

- показників продукту: чистий дохід від реалізації продукції /товарів, робіт, послуг (Форма № 2 «Звіт про фінансові результати»);

- показників прибутковості: чистий фінансовий результат прибуток / збиток (Форма № 2 «Звіт про фінансові результати»);

- оцінки якості через систему показників рентабельності, платоспроможності та ліквідності (Форми № 1, 2, 3, Примітки до річної звітності).

В основі вибору показників результативності - методичні рекомендацій щодо виявлення ознак неплатоспроможності підприємства та ознак дій із приховування банкрутства, фіктивного банкрутства чи доведення до банкрутства [11].

Альтернативний вибір показників із зазначеного в методичних рекомендаціях переліку для управлінського аналізу фінансово-господарської діяльності на прикладі виробничих підприємств (які готують повний пакет фінансової звітності) наведено в таблиці 1.

Альтернативна система результативних показників для управлінського аналізу фінансово-господарської діяльності на прикладі виробничих підприсмств

\begin{tabular}{|c|c|c|c|c|}
\hline \multirow{2}{*}{$\begin{array}{l}\text { № } \\
\left.3\right|_{\text {II }}\end{array}$} & \multirow{2}{*}{$\begin{array}{c}\text { Найменування по- } \\
\text { казника }\end{array}$} & \multicolumn{2}{|c|}{ Джерело інформації } & \multirow{2}{*}{ Примітки } \\
\hline & & Форма звітності* & Рядок/колонка & \\
\hline 1 & 2 & 3 & 4 & 5 \\
\hline & \multicolumn{3}{|c|}{ Показники затрат } & \\
\hline 1 & $\begin{array}{l}\text { Власні оборотні } \\
\text { активи }\end{array}$ & Форма № 1 & $\begin{array}{c}\text { Рядок } 1300- \\
\text { рядок } 1095\end{array}$ & $\begin{array}{l}\text { Валюта балансу за мінусом } \\
\text { необоротних активів на кінець } \\
\text { звітного періоду }\end{array}$ \\
\hline 2 & $\begin{array}{l}\text { Вартість основних } \\
\text { засобів (залишкова) }\end{array}$ & Форма № 1 & Рядок 1010 & $\begin{array}{l}\text { Первісна/переоцінена вартість } \\
\text { основних засобів за винят- } \\
\text { ком зносу на кінець звітного } \\
\text { періоду }\end{array}$ \\
\hline 3 & $\begin{array}{l}\text { Грошові кошти та їх } \\
\text { еквіваленти }\end{array}$ & Форма № 1 & Рядок 1165- 1167 & $\begin{array}{l}\text { Готівкові кошти в касі та без- } \\
\text { готівкові кошти на рахунках } \\
\text { у банку на кінець звітного } \\
\text { періоду }\end{array}$ \\
\hline \multirow[t]{2}{*}{4} & Запаси & Форма № 1 & Рядки 1100 - 1110 & $\begin{array}{l}\text { Активи, що використовують не } \\
\text { більше року або операційного } \\
\text { циклу на кінець звітного періоду }\end{array}$ \\
\hline & \multicolumn{3}{|c|}{ Показники продукту } & \\
\hline 5 & $\begin{array}{l}\text { Чистий дохід від } \\
\text { реалізації продукції } \\
\text { (товарів, робіт, по- } \\
\text { слуг) }\end{array}$ & Форма № 2 & Рядок 2000 & $\begin{array}{l}\text { Дохід без ПДВ від основної } \\
\text { операційної реалізації за звіт- } \\
\text { ний період }\end{array}$ \\
\hline \multirow[t]{2}{*}{6} & $\begin{array}{l}\text { Собівартість реалізо- } \\
\text { ваної продукції (това- } \\
\text { рів, робіт, послуг) }\end{array}$ & Форма № 2 & Рядок 2050 & $\begin{array}{l}\text { Прямі та загальновиробничі } \\
\text { витрати в частині реалізованої } \\
\text { продукції }\end{array}$ \\
\hline & \multicolumn{3}{|c|}{ Показники прибутковості } & \\
\hline 7 & $\begin{array}{l}\text { Фінансовий резуль- } \\
\text { тат від операційної } \\
\text { діяльності: Прибу- } \\
\text { ток/збиток }\end{array}$ & Форма № 2 & Рядок 2190/2195 & $\begin{array}{l}\text { Різниця між операційними } \\
\text { доходами й операційними ви- } \\
\text { тратами за звітний період }\end{array}$ \\
\hline 8 & $\begin{array}{l}\text { Чистий фінансовий } \\
\text { результат: Прибу- } \\
\text { ток/збиток }\end{array}$ & Форма № 2 & Рядок 2350/2355 & $\begin{array}{l}\text { Кінцевий фінансовий результат } \\
\text { діяльності до оподаткування за } \\
\text { звітний період }\end{array}$ \\
\hline
\end{tabular}




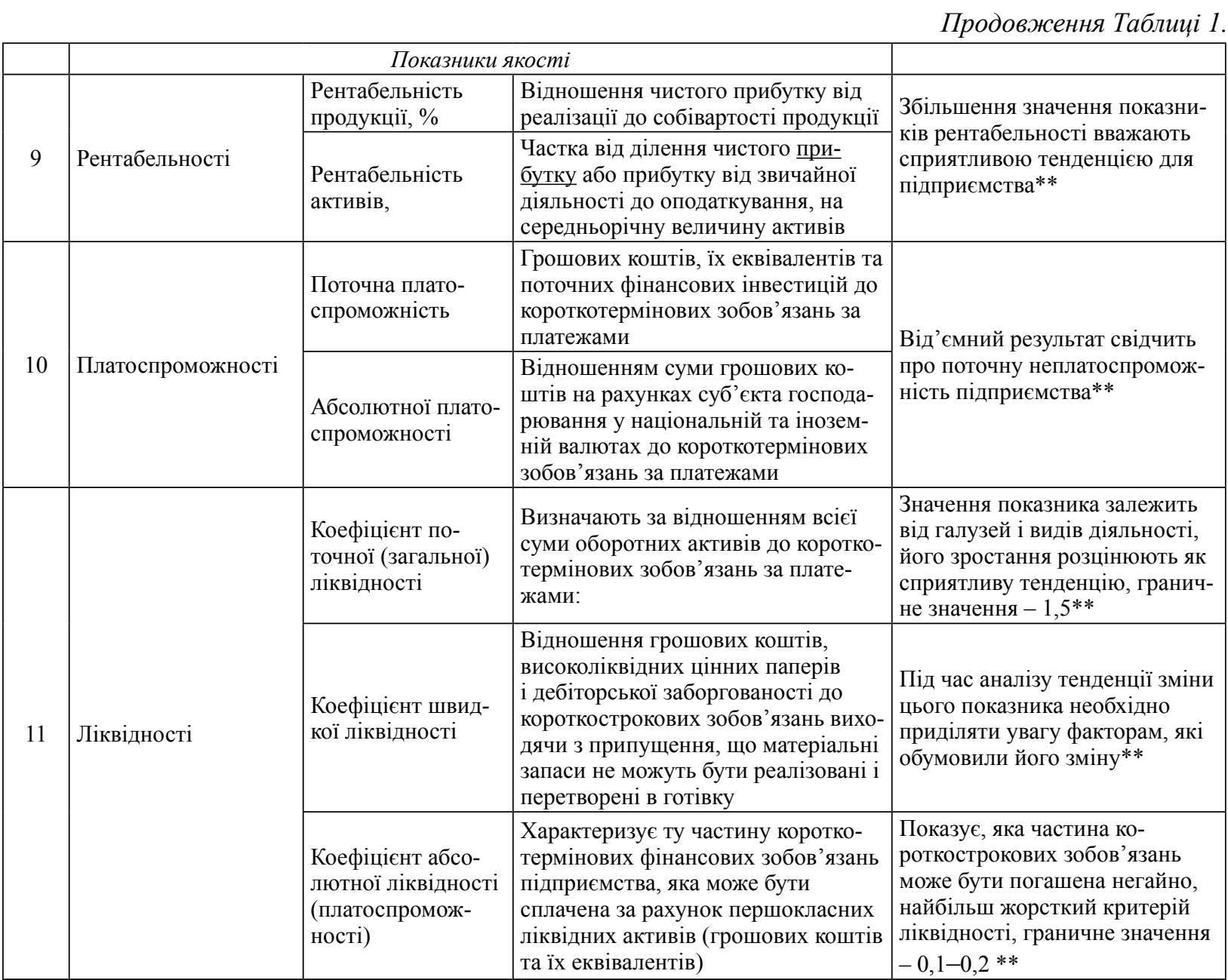

*Використані показники оприлюднюють у чинних формах фінансової звітності.

**Розрахунок показників узагальнено на основі $[7 ; 10 ; 11]$.

За аналогією до економічного аналізу, управлінський аналіз показників фінансового результату, залежно від предмету аналітичних процедур, класифікують так:

Горизонтальний аналіз проводять із метою вивчення динаміки окремих фінансових показників, розрахованих за даними фінансової звітності за певний період часу. Розраховують абсолютні та відносні зміни, темпи зростання (приросту) окремих показників (доходу, витрат, активів тощо) за ряд періодів і визначають загальні тенденції ї змін.

Вертикальний аналіз використовують для дослідження структури засобів і джерел їх утворення шляхом визначення питомої ваги окремих статей у підсумкових даних та оцінювання цих змін. Окремо аналізують майно (отримане або знаходиться в оренді), основні засоби й інші необоротні активи, які знаходяться під заставою, з метою встановлення ймовірності стягнення цього майна.

Параметричний/коефічієнтний аналіз фінансових результатів - використовують для оцінки відносних показників, що впливають на формування кінцевих параметрів фінансового результату виробничого підприємства, з метою порівняння їх на рівні галузі, відокремлених структур, ринкових кластерів тощо.

У практичній діяльності горизонтальний і вертикальний види аналізу виробничого підприємства застосовують до показників затрат, продукту та прибутковості, а параметричний - до показників оцінки якості.

За часовим аспектом управлінський аналіз (як у міжнародній, так і у вітчизняній практиці аналізу) класифікують на попередній, поточний, наступний, перспективний.

Не можна нівелювати роль управлінського аналізу в процесі управління як елемента зворотного зв'язку між керуючою і керованою системами. Зворотний зв'язок показує, як вплинули на виробничогосподарський процес певні управлінські рішення. Це дозволяє здійснити пошук альтернативних рішень, змінити напрям і методи роботи. Зворотний зв'язок доповнює інструментарій управлінського аналізу набором технічних прийомів і соціальних комунікацій.

Міжнародна практика зворотного зв'язку в управлінському аналізі вибудовується так, що оперативні управлінські рішення приймаються на нижчих рівнях по максимуму вихідних даних: 
І рівень - збір первинної інформації;

II рівень - оперативний: проводять систематизацію й узагальнення первинних даних;

III рівень - тактичний: передбачає звіт про виконання планів (у межах поставлених виконавцям такого зворотного зв'язку завдань);

IV стратегічний рівень: зведення попередніх звітів із метою створення загальної оцінки розвитку на предмет відповідності попередньому плануванню.

Висновок. Отже, інтеграція виробничих підприємств у міжнародні ринки обумовлює потребу розвитку методичного й організаційного інструментарію економічного аналізу господарської діяльності. Менеджери потребують не тільки дослідження показників фінансового результату, але й внутрішньої виробничої інфраструктури, їх впливу на формування доходів, витрат, прибутку/збитку.

Саме управлінський аналіз, використовуючи результати аналітичних процедур економічного аналізу (за його видами) фінансових результатів, доповнюючи їх інформацією щодо оцінки управлінських підходів у питаннях формування й оптимізації досліджуваних показників, дозволить повною мірою забезпечити менеджерів інформаційною базою для прийняття ефективних рішень в оперативному періоді і на перспективу.

\section{Лiтература:}

1. Бухгалтерський управлінський облік: підручник / Ф. Ф. Бутинець, Т. В. Давидюк, 3. В. Канурна та ін. Житомир: ПП «Рута», 2005. - 480 с.

2. Вахрушина М. А. Бухгалтерский управленческий учет: учеб. пособ. М. : ЗАО «Финстатинформ», 1999. - $359 \mathrm{c}$.

3. Замула I. В., Примак Т. С. Організація аналізу фінансових результатів в межах маркетингового дослідження конкурентних переваг. Вісник ЖДТУ. 2016. № 2 (76). С.11.

4. Гончарук Я. А., Рудницький В. С. Аудит: навч. посіб. К.: Знання, 2007. 443 с.

5. Пушкар М. С. Креативний облік (створення інформації для менеджерів): Монографія. Тернопіль, Картбланш, 2006. $-334 \mathrm{c}$.

6. Сопко В. В. Бухгалтерський облік в управлінні підприємством: Навч. посіб. - К.: КНЕУ, 2006. - 526 с.

7. Хорнгрен Ч. Т., Фостер Дж. Бухгалтерский учет: Управленческий аспект / Пер. с англ. М.: Финансы и статистика, 1995. - $416 \mathrm{c}$.

8. Бартош О. М. Управлінський облік, як основа ефективної системи управління банком [Електронний ресурс] // Фінансовий простір. - 2014. - № 1(13). - С. 36-42. - Режим доступу: http://fp.cibs.ck.ua/ files/1401/14bomuoj.pdf.

9. Імітаційні технології [Електронний ресурс]. - Режим доступу:. https://uk.wikipedia.org/wiki.

10. Оптимізація бізнес-процесів [Електронний ресурс]. - Режим доступу: http://www.businessstudio.ru/ article/printsipy_optimizatsii_biznes_protsessov.

11. Методичні рекомендації щодо виявлення ознак неплатоспроможності підприємства та ознак дій 3 приховування банкрутства, фіктивного банкрутства чи доведення до банкрутства [Електронний ресурс]: Наказ Міністерства економіки України від 19.01. 2006р. за № 14. - Режим доступу: http://www.me.gov.ua/Documents/ Detail?lang=uk-UA\&id=111503bd-ca7f. 